\title{
Alkylation of benzene with ethanol over modified HZSM-5 zeolite catalysts
}

\author{
Abdi Nemera Emana · Shri Chand
}

Received: 20 November 2014 / Accepted: 5 February 2015/Published online: 20 February 2015

(C) The Author(s) 2015. This article is published with open access at Springerlink.com

\begin{abstract}
Alkylation of benzene with ethanol was analysed using unmodified as well as modified shape selective HZSM-5 ( $\mathrm{Si} / \mathrm{Al}=31)$ zeolite catalysts. The reaction was carried out in a continuous fixed bed flow reactor in the temperature range of $300-500{ }^{\circ} \mathrm{C}$ at atmospheric pressure to investigate the activity of various catalysts for the selectivity and yield of ethylbenzene (the desired product). The alkylation of benzene with ethanol (2:1 by volume) produces ethyl benzene as primary product and others like diethylbenzene, triethylbenzene and xylene mixtures as secondary products. The modification of HZSM-5 was done by impregnation using boron and magnesium. The modification caused changes in the surface area, acidity and pore volume of zeolite sample. The physiochemical properties of catalysts were characterised by XRD, TEM, BET, TGA, FTIR, $\mathrm{NH}_{3}$-TPD and SEM. The feed and products were analysed by gas chromatography. The conversion of benzene was found to be better in bi metallic (B and $\mathrm{Mg}$ ) modified HZSM-5 followed by unmodified HZSM-5. The modified catalysts gave better selectivity $(72.8 \%)$ and yield (38.1\%) of ethylbenzene.
\end{abstract}

Keywords Alkylation - HZSM-5 - Bimetallic · Benzene · Ethanol · Ethylbenzene

List of symbols
$\lambda$
$\theta$
$D$

\author{
Bragg's angle of diffraction \\ Crystal size
}

$\mathrm{L}$

$\mathrm{H}_{\mathrm{s}}$

$\mathrm{H}_{\mathrm{r}}$

B

E

$\mathrm{T}$

(P, m, o,)-Xylene

DEB

TEB

SAR

WHSV

$\mathrm{X}_{\mathrm{B}}$

$\mathrm{S}_{\mathrm{EB}}$

$\mathrm{Y}_{\mathrm{EB}}$

TEM

TGA

SEM

XRD
The peak width at half height Peak height for the sample Peak height for the reference Benzene Ethanol Toluene (Para, Meta, Ortho)-Xylene respectively

Diethylbenzene

Triethylbenzene Silicon to aluminium ratio Weight hour space velocity Benzene conversion Selectivity of ethylbenzene Yield of ethylbenzene Transmission electron microscope Thermo-gravimetric analysis Scanning electron microscope X-ray diffraction

\section{Introduction}

Ethylbenzene (EB), which is one of the most important products used as the chemical intermediate, is the main feedstock for the synthesis of styrene which is then polymerised into polystyrenes [1]. Ethylbenzene is also used in the chemical industry in the manufacture of acetophenone, cellulose acetate, diethylbenzene (DEB), ethyl anthraquinone, ethylbenzene sulfonic acids, propylene oxide, and $\alpha$-Methyl benzyl alcohol [2]. Additionally, it is used as a solvent, a constituent of asphalt and of naphtha, and in fuels. Ethylbenzene and xylene mixture are used in the paint industry and in the production of pesticides in agriculture [2].

A. N. Emana $(\bowtie) \cdot S$. Chand Technology Roorkee, Roorkee, Uttarakhand, India 247667 e-mail: abdiharar@gmail.com

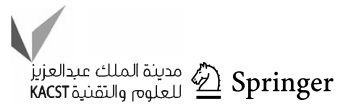


In the 1930s, Ethylbenzene was first produced on the commercial scale in Germany and the United States. Its production increased during World War II because of the high demand for synthetic polystyrene, i.e. butadiene rubber. The significant improvement in this technology led to the expansion in its capacity [3]. The current industrial production of ethylbenzene is based on benzene alkylation with ethene forming ethylbenzene in the presence of an acidic catalyst [4]. The overall equation of benzene alkylation with ethene is given as follows (see Fig. 1).

This conventional ethylbenzene production route is accompanied by successive reaction steps. Approximately, $5-15 \%$ of the ethylbenzene reacts further with ethene forming diethylbenzene and about $10-20 \%$ of the diethylbenzene converts into triethylbenzene (TEB) by alkylation with ethene. A stoichiometric excess of benzene in the alkylation loop is able to minimise the alkylation of triethylbenzene with ethene forming polyethylated benzene. The diethylbenzene and triethylbenzene would be recovered and react with benzene in the transalkylation reaction reproducing ethylbenzene [5].

In the 1950s, the world's ethylbenzene capacity produced in Friedel-Crafts liquid-phase alkylation with aluminium chloride-based $\left(\mathrm{AlCl}_{3}\right)$ catalysts was about $40 \%$ [4]. In the $1960 \mathrm{~s}$, supported catalysts such as $\mathrm{BF}_{3} / \mathrm{Al}_{2} \mathrm{O}_{3}$ and supported phosphoric acid (SPA) were proposed to replace the $\mathrm{AlCl}_{3}$-based catalysts [6]. However, the processes catalysed by either SPA or $\mathrm{AlCl}_{3}$-based FriedelCraft catalysts, suffer from serious environmental and corrosion problems [7]. The disposal of unavoidable byproducts formed in stoichiometric reactions, such as oxidation, has raised serious environmental problems [8]. In addition, the catalysts involved in the alkylation reactions, i.e. either strong mineral acids or Lewis acids, are highly toxic and corrosive, and are capable of corroding storage and disposal containers [6]. Moreover, the catalystrecycling step in solid phosphoric acid catalysed processes raises difficulties in the process arrangement. The necessity for complete removal of traces of catalyst from the product after catalyst deactivation, to avoid the deterioration of the product, is a further challenge faced in the processes catalysed by non-environmental friendly catalysts [9].

The development of the process producing ethylbenzene was improved markedly in the 1980s when a new gas-
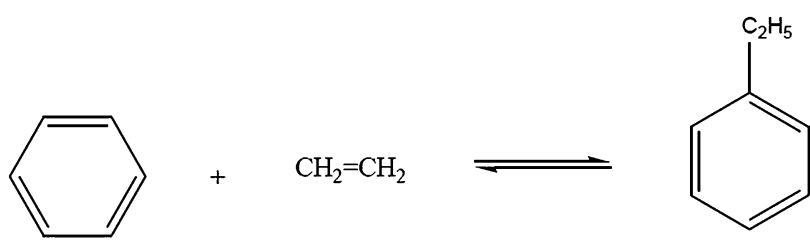

Fig. 1 The overall equation of benzene alkylation with ethene [4] phase alkylation process using zeolite-based catalysts was commercialised, overcoming the main drawbacks of the $\mathrm{AlCl}_{3}$ and supported phosphoric acid technology [4, 6]. These zeolite catalysed processes are licensed by MobilBadger, Lummus-UOP, CDTech, and Dow Chemical [4].

Several authors have proposed the alternative catalytic reaction pathways for the production of ethylbenzene. The catalytic reaction which uses ethanol for benzene alkylation, instead of ethene, would eliminate the ethene production step and, therefore, leading to the commercial and environmental benefits in the ethylbenzene manufacturing [10]. In addition to the intrinsic scientific interest, the direct use of ethanol (instead of ethene) in the manufacture of ethylbenzene also has economic significance in those countries like Brazil and India, where biomass-derived alcohol is an additional feedstock for the manufacture of chemicals (see Fig. 2).

Several studies have been reported regarding benzene alkylation using unmodified zeolites like HZSM-5, Beta, HY, mordenite, TNU-9, SSZ-33,ZSM-12, MCM-22 and ITQ-22 [6, 12-16] as well as HZSM-5 modified with phosphorous and boron [10]. Venuto et al. [13] had already shown that although Linde type $\mathrm{X}$ and $\mathrm{Y}$ zeolites exchanged with rare earth ions catalyse the alkylation of benzene with ethanol, the catalyst aging was severe leading to catalyst deactivation in a few hours. Li et al. [17] had performed alkylation of benzene with ethanol for synthesis of ethylbenzene over parent zeolites and zeolites modified with $\mathrm{La}_{2} \mathrm{O}_{3}$, such as HMCM-22, HBeta and nano HZSM-5.

The properties of catalysts must be carefully tuned for the desired catalytic process before use. Zeolites are crystalline aluminosilicate, and their acid-base properties depend on the aluminium content in the framework. The adjustment of the acidity may be realised by proper $\mathrm{SiO}_{2} /$ $\mathrm{Al}_{2} \mathrm{O}_{3}$ molar ratio, crystallisation, other elements replacing framework constituents, or modification of the zeolite [21].

In the reaction of converting benzene to ethylbenzene, zeolite (HZSM-5) has been used as a catalyst. It is well known that the alkylation reaction of benzene in the presence of an acid catalyst belongs to a carbenium ion type mechanism, and both Brønsted acid site and Lewis acid site are the active sites. Unmodified HZSM-5 catalysts have numerous micro-porous void spaces and strong acidic sites, leading to the generation of secondary products like diethylbenzene. These two drawbacks result in lower selectivity and a variety of secondary reactions in the alkylation process. One way to improve selectivity toward ethylbenzene is to change the acidity of HZSM-5 by introducing an additive compound into the zeolite system.

Alkaline-earth metals have similar alkaline properties to alkali metals while their oxides have some properties (such as high melting points) similar to silica and alumina. Magnesium suppresses the carbonisation of catalysts [18]. 
Fig. 2 Primary and secondary reactions occurring during ethylation of benzene with ethanol [11]

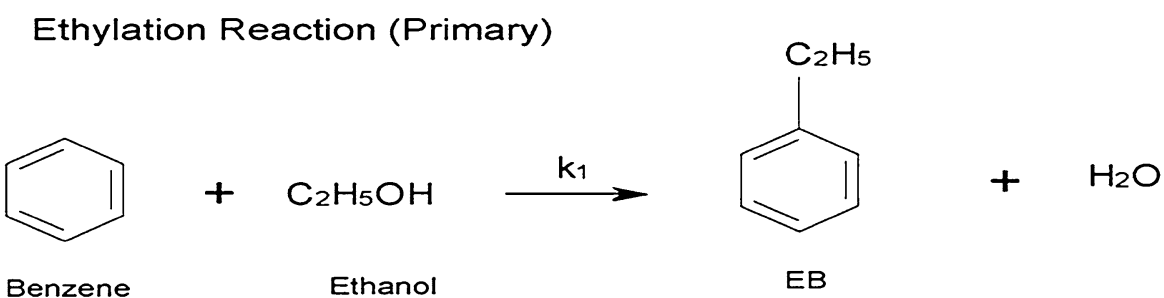

Ethylation Reaction (Secondary)<smiles>CCCc1cccc(CC(CC)c2ccccc2CCc2cccc(CC(CC)c3ccccc3)c2)c1</smiles>

Therefore, modification of the zeolite catalyst by boron and/or magnesium reduces the number of acidic sites on its external surface by coating the catalyst and reduces coke formation. This facilitates the shape selective alkylation reaction inside the pores and also to reduce further oligomerisation reaction. This research focused on the development of the promising catalyst for benzene alkylation with ethanol into ethylbenzene. Modification of catalyst (HZSM-5) was carried out by impregnation of magnesium and boron producing Mg (5\%)-HZSM-5 and B (4\%)-HZSM-5.

\section{Experimental}

\section{Materials}

Sodium ZSM-5 zeolite in the form of powder with SAR-31 obtained from Sud-Chemie India Pvt. Ltd. Benzene used for the experiments was $99 \%$ pure. Boric acid $(99.5 \%$ pure) and benzene for the present study were obtained from RFCL limited, A-3, Okhla Industrial Area, Phase-I, New Delhi, India. Pure ethanol (99.9 \%) was supplied by Merck KGaA, 64271 Darmstadt, Germany. Magnesium nitrate (99\% pure) and ammonium nitrate extra pure (98\%) were supplied by HiMedia laboratories Pvt. Ltd. Mumbai, India.

\section{Catalyst preparation}

Sodium ZSM-5 zeolite in the form of powder with SAR-31 obtained from Sud-Chemie India Pvt. Ltd was transformed to protonic form by repeated exchange using $1 \mathrm{M}$ solution of ammonium nitrate four times and each time for $6 \mathrm{~h}$ using fresh solution of ammonium nitrate at $55^{\circ} \mathrm{C}$ under reflux and stirring. After that, zeolite was separated from ammonium solution, washed and dried over night at $120{ }^{\circ} \mathrm{C}$. The catalyst was then calcined at $550{ }^{\circ} \mathrm{C}$ for $5 \mathrm{~h}$. HZSM-5 zeolite was impregnated with magnesium and boron using the same weight percent $(8 \%)$. The sources of magnesium and boron were from magnesium nitrate and boric acid, respectively. However, atomic absorption and inductive coupling plasma mass spectroscopy test results showed that $5 \%$ magnesium and $4 \%$ boron were incorporated to HZSM-5 zeolite. The contents were further heated at $55^{\circ} \mathrm{C}$ overnight under total reflux and stirring. The solutions were subsequently filtered. The filtered solid was dried at $120{ }^{\circ} \mathrm{C}$ overnight and calcined at $550{ }^{\circ} \mathrm{C}$ for $5 \mathrm{~h}$ in a muffle furnace. The zeolite powder so obtained was pelletised at 10 tonne $/ \mathrm{cm}^{2}$ pressure and broken into small pieces in the size range $0.3-0.5 \mathrm{~mm}$. The fraction in this size range was used in the reactor for the activity test runs.

\section{Experimental setup}

The catalytic experiments were carried out in a fixed bed; continuous down flow tubular quartz reactor $(0.6 \mathrm{~cm} \mathrm{I.} \mathrm{D}$ and $66 \mathrm{~cm}$ long) was placed inside a microprocessor controlled furnace (Metrex Scientific Instruments Pvt. Ltd, New Delhi) preceded by a pre-heater and followed by a condenser. The same reactor tube was used in all the experiments. In a typical run, about $0.7 \mathrm{~g}$ of catalyst (which occupied $6 \mathrm{~cm}$ height of the reactor) was charged into the reactor and the reaction was carried out at atmospheric pressure using unmodified as well as modified HZSM-5 catalyst. The catalyst was activated for $1 \mathrm{~h}$ in an atmosphere of nitrogen before the experimental runs were 
started. The benzene ethanol mixture which was $2: 1$ ratio introduced with the help of a metering pump at rate of $0.4 \mathrm{ml} / \mathrm{min}$ and vaporised in the pre-heater before contacting the catalyst. The reactant vapours along with nitrogen entered the reactor, which was electrically heated. The flow rate of the carrier gas nitrogen was $0.5 \mathrm{l} / \mathrm{min}$. The products vapours, along with unreacted reactants, were condensed in the condenser and the liquid samples collected were analysed in a gas chromatograph with a $30 \times 0.25 \mathrm{~mm}(0.25 \mu \mathrm{m}$ film thickness $)$ Agilent HP-88 capillary column using a flame ionisation detector (FID). The program used was as follows. Initial oven temperature was $70{ }^{\circ} \mathrm{C}$ and then held for $2 \mathrm{~min}$. After that, the temperature was increased to $200{ }^{\circ} \mathrm{C}$ with a ramp rate of $10{ }^{\circ} \mathrm{C} / \mathrm{min}$. Again it stayed at $200{ }^{\circ} \mathrm{C}$ for $1 \mathrm{~min}$. The Detector and Injection temperature were $250{ }^{\circ} \mathrm{C}$. Flow rate of air, hydrogen and nitrogen was 350,25 and $35 \mathrm{ml} / \mathrm{min}$, respectively. Nitrogen was used as carrier gas and the split ratio was $1: 50$.

From gas chromatography results, the selectivity and yield of ethylbenzene in the product were calculated. The conversion of benzene was also noted for modified as well as unmodified HZSM-5 catalysts.

\section{Catalyst characterisation}

\section{BET analysis}

The BET surface area and the pore volume of the catalyst samples were determined by liquid nitrogen adsorption at $-196{ }^{\circ} \mathrm{C}$ using Micromeritics ASAP 2020 instrument. Degassing was done for $8 \mathrm{~h}$ under vacuum at $250{ }^{\circ} \mathrm{C}$. The BET surface area, external surface area and total pore volume decreased with doping of boron and magnesium ions as shown in Table 1. This may be due to the blockage of the channel by metal cations used for modification.

\section{$X R D$ analysis}

XRD analysis was carried out using powder diffractometer (Bruker D8) at Institute Instrumentation Centre (IIC), Indian Institute of Technology Roorkee. $\mathrm{Cu}-\mathrm{K} \alpha\left(\lambda=1.5417 \mathrm{~A}^{\circ}\right.$,

Table 1 BET surface area of different types of catalysts

\begin{tabular}{lllll}
\hline $\begin{array}{l}\text { Types of } \\
\text { catalysts }\end{array}$ & $\begin{array}{l}\text { BET } \\
\text { surface } \\
\text { area }\left(\mathrm{m}^{2} / \mathrm{g}\right)\end{array}$ & $\begin{array}{l}\text { External } \\
\text { surface } \\
\text { area }\left(\mathrm{m}^{2} / \mathrm{g}\right)\end{array}$ & $\begin{array}{l}\text { Total pore } \\
\text { volume } \\
\left(\mathrm{cm}^{3} / \mathrm{g}\right)\end{array}$ & $\begin{array}{l}\text { Average pore } \\
\text { width }(4 \mathrm{~V} / \mathrm{A} \\
\text { by BET) }(\AA)\end{array}$ \\
\hline Unloaded HZSM-5 & 349 & 134 & 0.22 & 25.05 \\
Mg (5 \%)-HZSM-5 & 308 & 105 & 0.20 & 25.44 \\
B (4 \%)-HZSM-5 & 278 & 58 & 0.18 & 25.46 \\
$\begin{array}{l}\text { Mg (5 \%)-B (4 \%) } \\
\text { HZSM-5 }\end{array}$ & 270 & 74 & 0.17 & 25.75 \\
\hline
\end{tabular}

$40 \mathrm{kv}$ and $30 \mathrm{~mA}$ ) was used as anode material and the range of scanning angle $(2 \theta)$ was kept between $5^{\circ}$ and $120^{\circ}$ with scan speed of $2 \theta=1 \% \mathrm{~min}$. The powder XRD patterns (Fig. 3) of all the four samples exhibited well-resolved diffraction peaks, which were characteristics of the MFI framework structure. The high intensity of peaks in the XRD patterns indicates that the zeolite samples were highly crystalline materials and the highest diffraction peaks were seen at $2 \theta=23^{\circ}$. There is no mismatch in the pattern of peaks for $\mathrm{a}, \mathrm{b}$ and $\mathrm{d}$ in Fig. 3, so no other phase formation was found. However, a new peak was appeared for (c) around $28^{\circ}$ in the XRD pattern. This is due to the formation of $\mathrm{B}_{2} \mathrm{O}_{3}$ as a new phase. The peaks were shifted towards higher $2 \theta$ values either due to internal stress or change in interplanar distance. Greater shift was found for boron modified. The reason may be the incorporation of the metal cation into the framework and formation of new phase. All the modified samples were found to be highly crystalline. The XRD patterns were used to calculate the average crystal size and the relative crystallinity of the different zeolites. The average crystal sizes were estimated using the Scherrer equation.

$D=\frac{\mathrm{k} \lambda}{L \operatorname{Cos} \theta}$

where $D$ is the crystal size, $k$ is a constant $(0.99), \lambda$ is the $\mathrm{X}$ ray wavelength $(\lambda=0.1542 \mathrm{~nm}), L\left(0.5 * \frac{\pi}{180}\right)$ the peak width at a half-height (in radians) and $\theta$ the Bragg's angle of diffraction.

The relative crystallinity of the modified zeolites was calculated by comparing the average intensities of the most intense peaks with that of the parent zeolite, HZSM-5, assuming $100 \%$ of crystallinity for the starting material. The calculations were made according to the standard methods ASTM D 5758 for ZSM-5 zeolites.

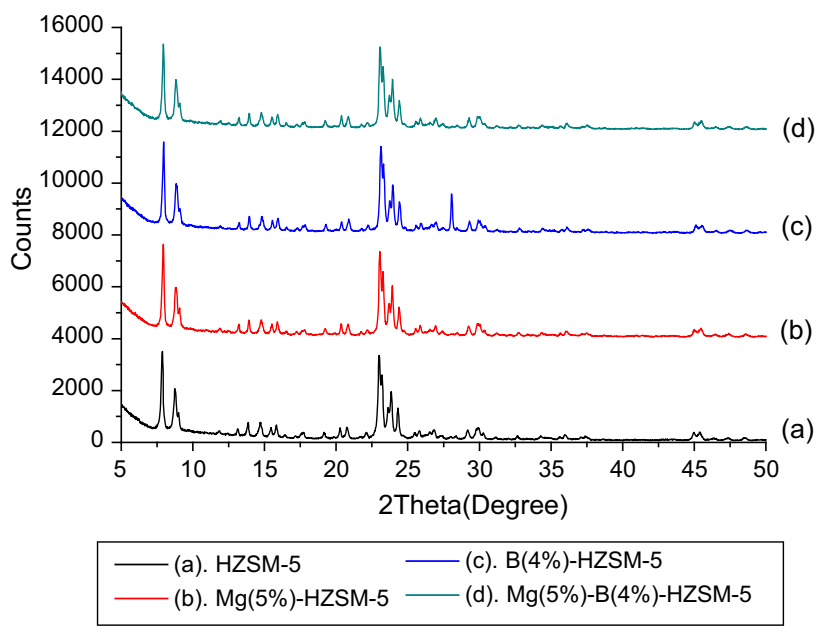

Fig. 3 X-ray diffraction patterns of unmodified and modified HZSM-5 
\%XRD Relative Crystallinity of HZSM - 5

$$
=\frac{\mathrm{H}_{\mathrm{s}}}{\mathrm{H}_{\mathrm{r}}} \times 100 \%
$$

where $H_{\mathrm{s}}$ is the peak height for the sample, and $H_{\mathrm{r}}$ is the peak height for the reference.

As we can see from Table 2, the crystal size of the modified and unmodified HZSM-5 was the same but the relative crystallinity was highest for $4 \% \mathrm{~B}-\mathrm{HZSM}-5$, while the lowest crystallinity was for $4 \% \mathrm{~B}-5 \% \mathrm{Mg}-\mathrm{HZSM}-5$.

\section{FE-SEM and TEM}

The morphology of the zeolite samples was evaluated by transmission electron microscopy (tem) and field emissionscanning electron microscope (FE-SEM) using a TEM TECNAI G 20 S-TWIN and ULTRA plus, respectively. TEM images of the samples are shown in Fig. 4. TEM results showed that modified zeolite was in good agreement with XRD results as there were no major changes in the structure (morphology). In this way, it was possible to confirm that the particle sizes and morphologies remained unchanged during the impregnation treatments. The zeolite was able to keep its structure even after loading with boron and magnesium. Further, TEM imaging shows rough surface and irregular shape of the crystal. The presence of boron and magnesium on the surface of zeolite crystallites was identified using EDAX. The elemental chemical analyses performed by Atomic Absorption Spectroscopy (AAS) (Avanta M) and Inductive Coupling Plasma Mass Spectroscopy (ICP-MS) (Perkin Elmer) also support the EDAX result shown in Fig. 6.

The morphology of the parent and modified HZSM-5 zeolite catalyst crystals is indicated as shown in Fig. 5 using SEM. It can be seen that the individual particles form larger and irregular aggregates and, therefore, difficult to determine the mean size of the primary particles from the SEM image. The FE-SEM photographs reveal a change in the morphology of HZSM-5 upon modification with boron and magnesium. A comparison between modified and unmodified HZSM-5 reveals the appearance of cavities and

Table 2 Relative crystallinity and crystal size of modified and unmodified HZSM-5

\begin{tabular}{llll}
\hline No. & Type of catalyst & $\begin{array}{l}\text { Crystal size } \\
(\mathrm{\AA})\end{array}$ & $\begin{array}{l}\text { Relative crystallinity } \\
(\%)\end{array}$ \\
\hline 1 & HZSM-5 & 180 & 100 \\
2 & $5 \%$ Mg-HZSM-5 & 180 & 97.7 \\
3 & $4 \%$ B-HZSM-5 & 180 & 98.2 \\
4 & $4 \%$ B-5 \%Mg- & 180 & 93.1 \\
& HZSM-5 & & \\
\hline
\end{tabular}

cages which facilitate the alkylation reaction and shape selectivity of the catalyst after modification.

\section{Thermo-gravimetric analysis}

Thermo-gravimetric analysis technique was conducted to determine the thermal stability of the zeolite framework and weight loss occurring from zeolite lattice during heating. TGA was conducted on SII 6300 EXSTAR using air as carrier gas at $200 \mathrm{ml} / \mathrm{min}$ on a $10 \mathrm{mg}$ of sample. Figure 7 presents the TGA of unmodified and modified HZSM-5 (Si/ $\mathrm{AL}$ ratio $=31$ ) heated from ambient temperature to $1,000{ }^{\circ} \mathrm{C}$ in temperature progression of $10^{\circ} \mathrm{C} / \mathrm{min}$. The portion of the curves up to $200{ }^{\circ} \mathrm{C}$ is normally linked with the weight loss due to moisture content of the catalyst, whereas the portion of the curves from 200 to $1,000{ }^{\circ} \mathrm{C}$ is assigned to the weight loss due to removal of hydrocarbon, moisture contained inside the pores and coke formation. $4 \%$ B-HZSM-5 catalyst had the lowest weight loss up to $550{ }^{\circ} \mathrm{C}$ but beyond this temperature the highest weight loss occurred. From ambient temperature to $1,000{ }^{\circ} \mathrm{C}$, the highest weight loss was seen for $4 \% \mathrm{~B}-\mathrm{HZSM}-5$ followed by $5 \% \mathrm{Mg}-\mathrm{HZSM}-5,4 \% \mathrm{~B}-5 \% \mathrm{Mg}-\mathrm{HZSM}-5$ and HZSM5 , respectively. The weight loss of $4 \% \mathrm{~B}-\mathrm{HZSM}-5$ between 650 and $900{ }^{\circ} \mathrm{C}$ is due to melting of $\mathrm{B}_{2} \mathrm{O}_{3}$ which is appeared as a new phase in XRD pattern. The percent weight loss of all the catalysts is given in Table 3.

\section{FTIR analysis}

Infrared spectra were obtained at $4 \mathrm{~cm}^{-1}$ resolution on Nicolet 6700 series FTIR Spectrometer. The infrared cell used was fitted with $\mathrm{KBr}$ windows and connected to a high vacuum $\left(10^{-3}\right.$ torr $)$ system. A sample of the zeolite powder was accurately weighed and mixed with around $300 \mathrm{mg} \mathrm{KBr}$ and then passed into a $10 \mathrm{~mm}$ diameter wafer at 15 tonnes $/ \mathrm{cm}^{2}$ pressure. This wafer was placed in the IR cell. The IR cell spectra were recorded at room temperature in air. Background IR correction for air was also made.

The IR structural studies of zeolite have been carried out in the infrared region of wave number $400-4,000 \mathrm{~cm}^{-1}$, because fundamental vibrations of $\mathrm{SiO}_{4}$, $\mathrm{AlO}_{4}$ or $\mathrm{TO}_{4}$ units are contained in this region. In the $\mathrm{KBr}$ pellet technique, a small amount of the solid sample was mixed with powdered $\mathrm{KBr}$ and pressed into pellet. In the pelletizing process, the $\mathrm{KBr}$ crystalline boundaries flow together and around the sample particles sufficiently, so that they do not scatter much light and the whole pellet looks more or less clear.

The band at (1) $545 \mathrm{~cm}^{-1}$ is assigned to the highly distorted double five membered rings present in the ZSM-5 structure, (2) $3,739,3,660$ and $3,490 \mathrm{~cm}^{-1}$ are assigned to 


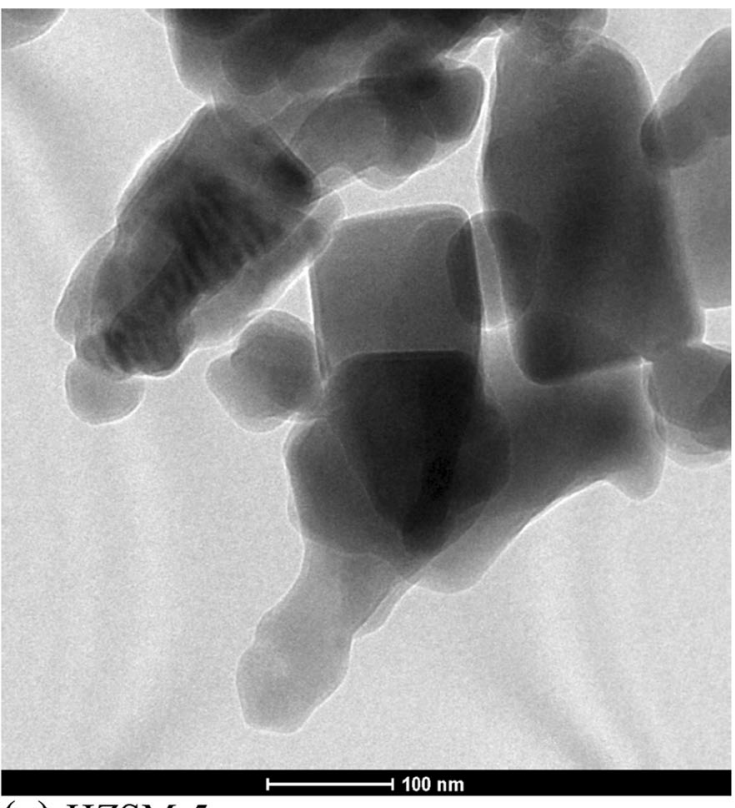

(a) HZSM-5

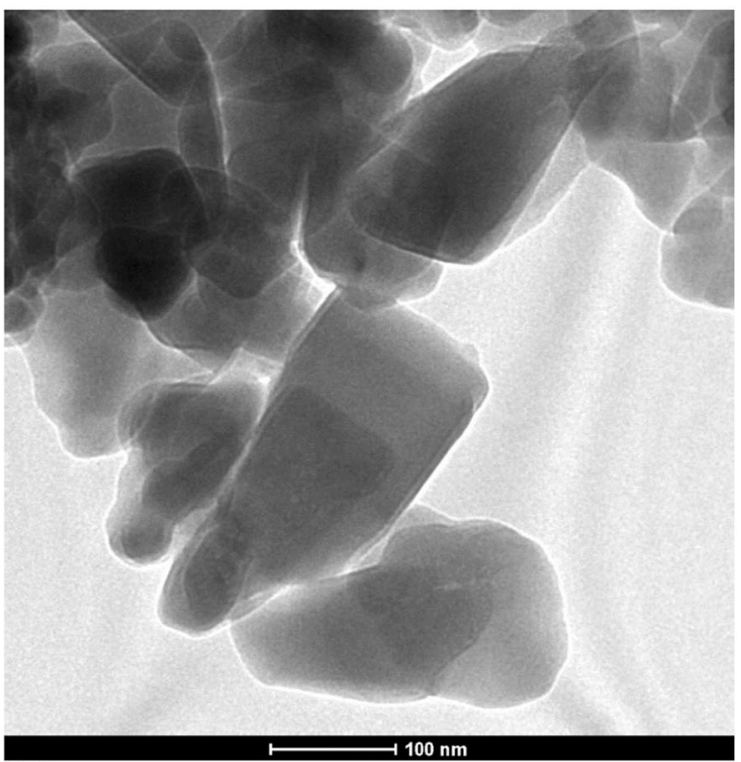

(c) $\operatorname{Mg}(5 \%)-\mathrm{B}(4 \%)-\mathrm{HZSM}-5$

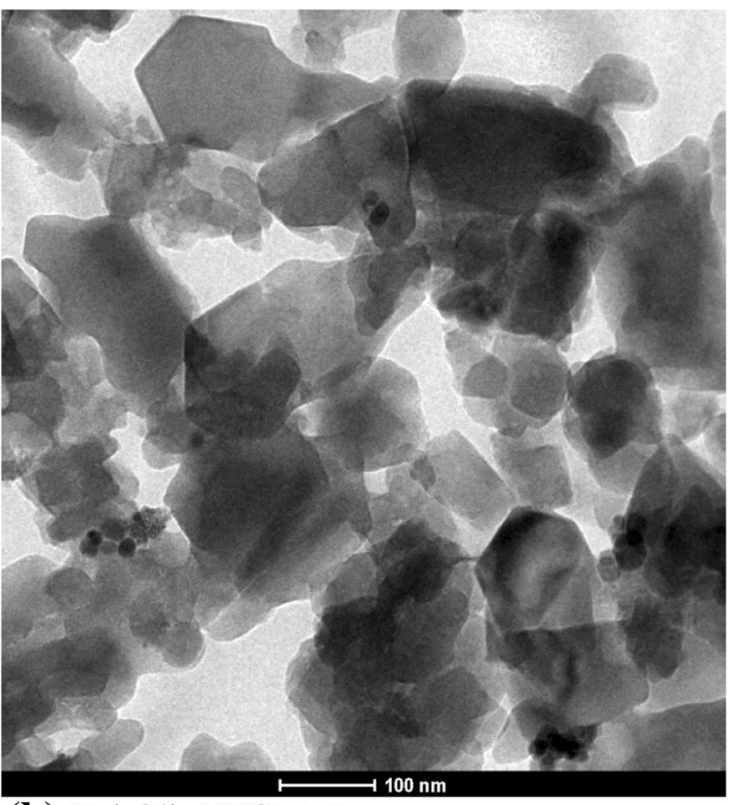

(b) B (4\%)-HZSM-5

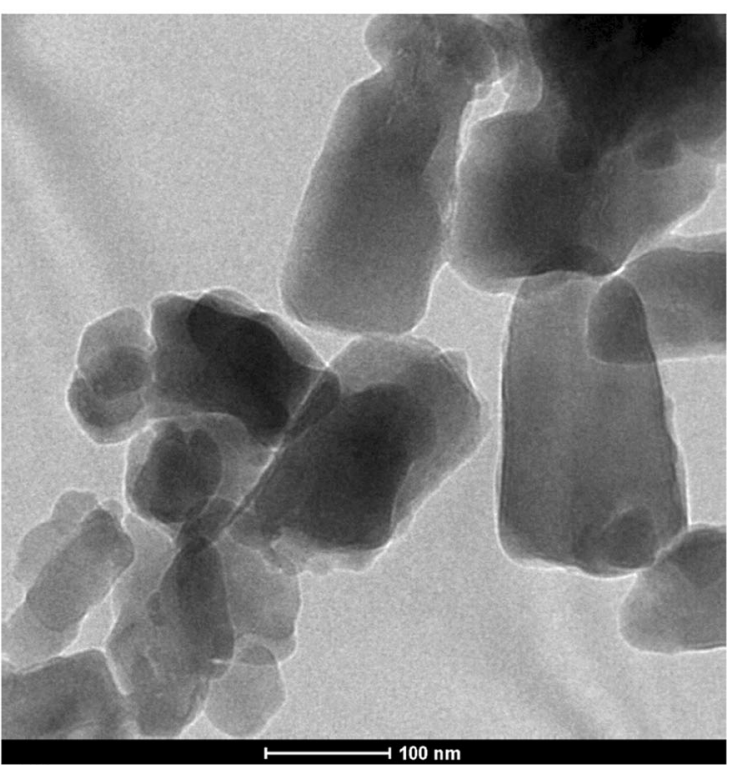

(d) $\mathrm{Mg}(5 \%)-\mathrm{HZSM}-5$

Fig. 4 Transmission electron microscopic results of unmodified and modified HZSM-5

weak, medium and strong Brønsted acid sites, respectively, (3) $1,700 \mathrm{~cm}^{-1}$ to water bond, (4) $800 \mathrm{~cm}^{-1}$ to $\mathrm{Al}-\mathrm{O}$ bond and (5) $1,350 \mathrm{~cm}^{-1}$ to $\mathrm{Si}-\mathrm{O}-\mathrm{Si}$ bond, etc. The values of the wave numbers mentioned above against particular characteristics may shift a little after the ion exchange process.

The approximate IR band corresponding to a functional group present in the HZSM-5 is suggested as below (see Fig. 8):

\begin{tabular}{ll}
\hline $\mathrm{Si}-\mathrm{OH}$ & $3,745 \mathrm{~cm}^{-1}$ \\
$\mathrm{Si}-\mathrm{OH}-\mathrm{Al}$ & $3,610 \mathrm{~cm}^{-1}$ (dependent on SAR) \\
$\mathrm{Al}-\mathrm{OH}$ & $3,600 \mathrm{~cm}^{-1}$ (in structure) \\
$\mathrm{H}-\mathrm{OH}$ & $1,660 \mathrm{~cm}^{-1}$ \\
$\mathrm{Si}-\mathrm{O}-\mathrm{Si}$ & $1,140 \mathrm{~cm}^{-1}$ \\
$\mathrm{Si}-\mathrm{O}-\mathrm{Al}$ & $1,075 \mathrm{~cm}^{-1}$ \\
$\mathrm{Al}-\mathrm{O}$ & $760 \mathrm{~cm}^{-1}$ \\
\hline
\end{tabular}



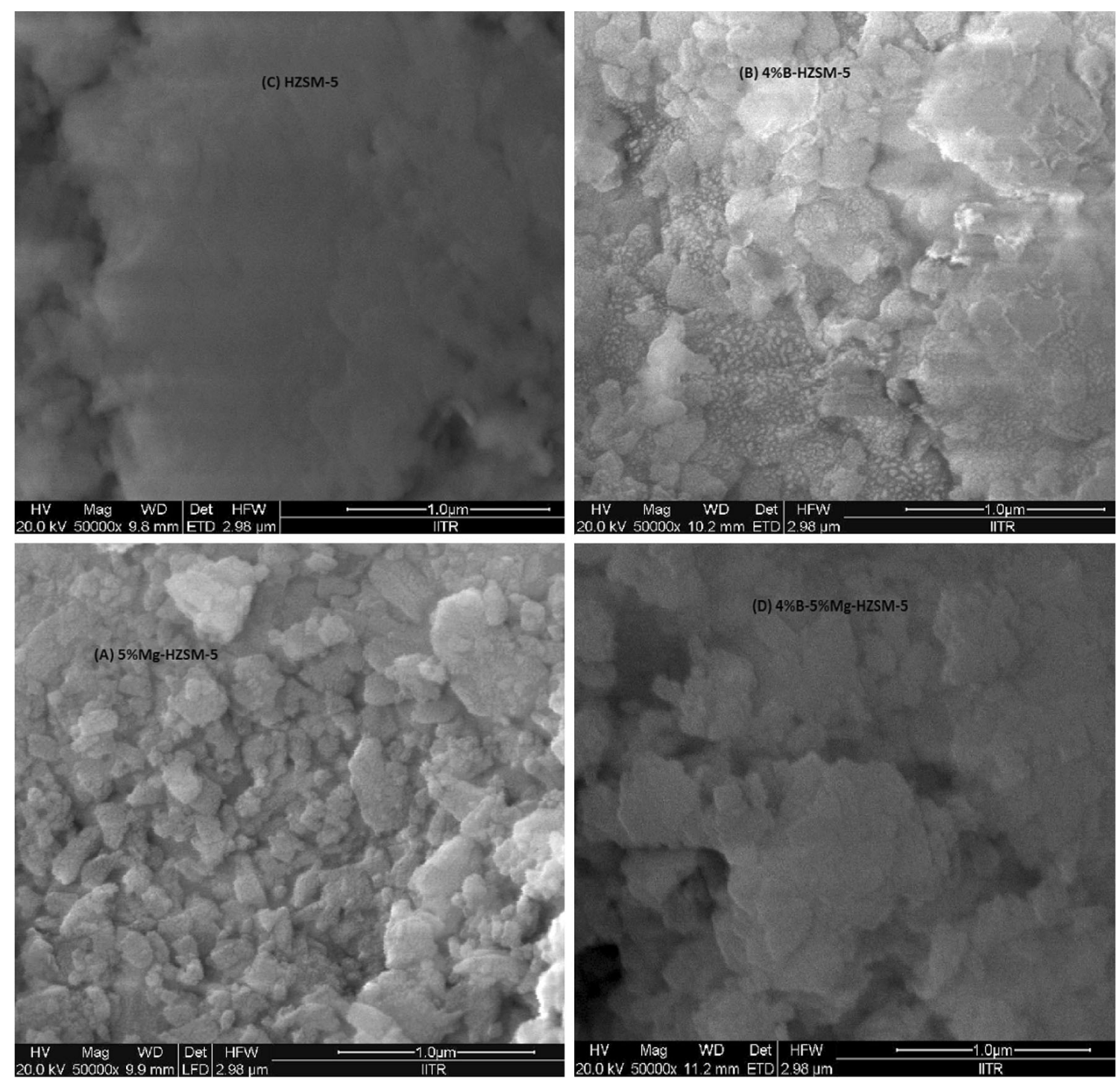

Fig. 5 Scanning electron microscopic results of unmodified and modified HZSM-5

\section{Temperature programmed desorption of ammonia $\left(\mathrm{NH}_{3}-\mathrm{TPD}\right)$}

$\mathrm{NH}_{3}$-TPD measurements in the range from room temperature to $650{ }^{\circ} \mathrm{C}$ were performed in a quartz cell with $\mathrm{U}$ shape micrometrics (ChemiSorb 2720). Zeolite samples were put in a quartz cell with $\mathrm{U}$ shape and pretreated, in situ, during $1 \mathrm{~h}$ at $250{ }^{\circ} \mathrm{C}$ in a flow of nitrogen $(>99 \%)$ of $20 \mathrm{ml} / \mathrm{min}$. After cooling to $25^{\circ} \mathrm{C}$, adsorption of ammonia was carried out in a flow of ammonia and helium mixture of $40 \mathrm{ml} / \mathrm{min}$. After the catalyst surface became saturated with ammonia and helium mixture for $20 \mathrm{~min}$, additional $5 \mathrm{~min}$ was waited to remove the excess ammonia. The temperature-programmed desorption was carried out with a linear heating rate of approximately $10{ }^{\circ} \mathrm{C} / \mathrm{min}$ from 25 to $650{ }^{\circ} \mathrm{C}$ in a flow of helium $(>99 \%)$ of $20 \mathrm{ml} / \mathrm{min}$. The $\mathrm{NH}_{3}$ that desorbed was measured by a thermal conductivity detector and the electrical signals from the detector and from the thermocouple (that measures the temperature inside the cell with the catalyst) were digitised by a CR3A chromatographic integrator and transmitted to a computer.

\section{Result and discussion}

The powder XRD patterns (Fig. 3) of all the four samples exhibited well-resolved diffraction peaks, which were characteristics of the MFI framework structure. The high intensity of peaks in the XRD patterns indicates that the zeolite samples were highly crystalline materials and the highest diffraction peaks were seen at $2 \theta=23^{\circ}$. There is no mismatch in the pattern of peaks for $a, b$ and $d$ in Fig. 3, so no other phase formation was found. However, a new 


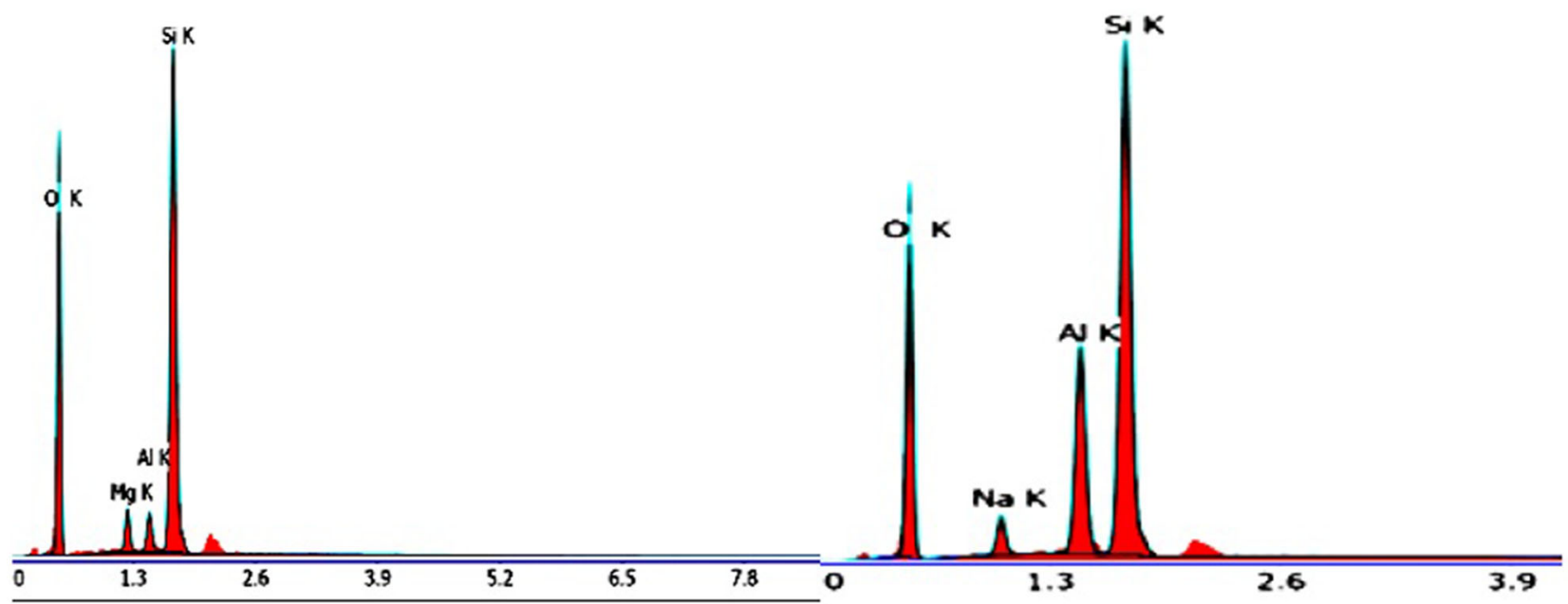

\section{$\mathrm{Mg}(5 \%)-\mathrm{HZSM}-5$}

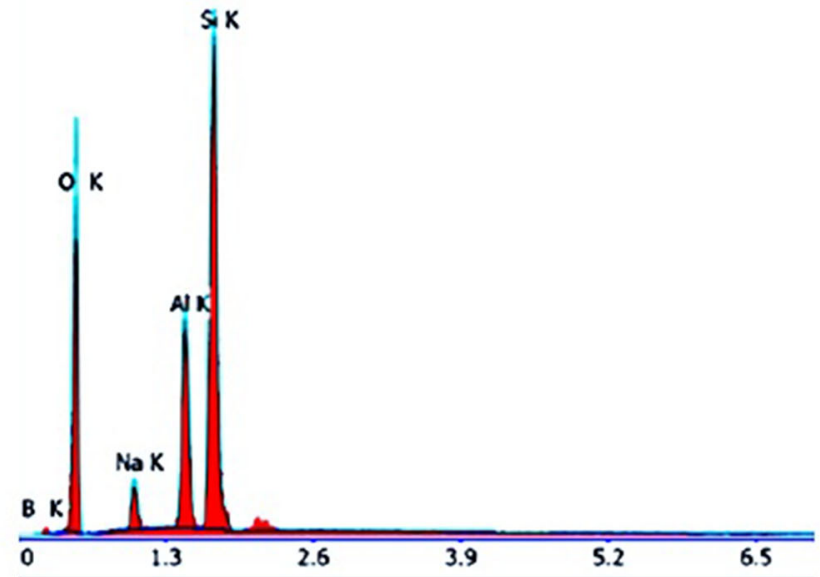

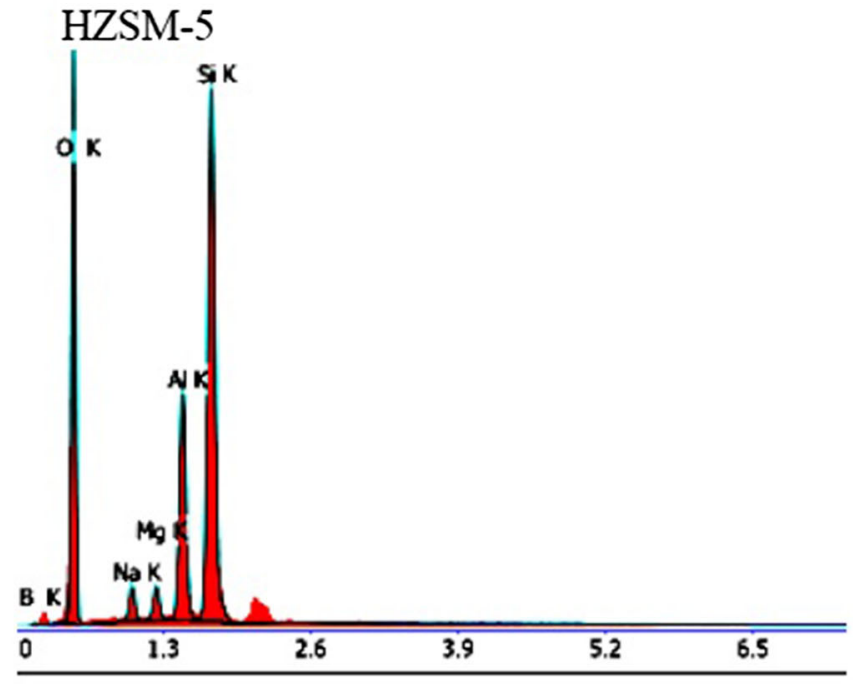

B(4\%)-Mg(5\%)-HZSM-5

Fig. 6 EDAX results of unmodified and modified HZSM-5

peak was appeared for (c) around $28^{\circ}$ in the XRD pattern. This is due to the formation of $\mathrm{B}_{2} \mathrm{O}_{3}$ as a new phase. The peaks were shifted towards higher $2 \theta$ values either due to internal stress or change in interplanar distance. Greater shift was found for boron modified. The reason may be the incorporation of the metal cation into the framework and formation of new phase. All the modified samples were found to be highly crystalline but relative crystallinity decreased.

The temperature programmed desorption of a basic molecule such as ammonia ( $\mathrm{NH}_{3}$-TPD) is one of the most commonly used methods used for measuring the surface acidity of porous materials, such as zeolites, clays or mesoporous silica [19].

The acid strength can be determined by measuring the heat of adsorption or desorption of a suitable probe molecule. Ammonia meets the requirements for such a probe. Firstly, it is small enough to enter all the zeolite pores. Secondly, it can react both with the Brønsted and Lewis acid sites [20].

From the $\mathrm{NH}_{3}$-TPD experiments (Fig. 9), it could be concluded that two types of acid sites were present in H-ZSM-5: Weak acid sites corresponding with desorption at low temperature and strong acid sites corresponding with desorption at high temperature (see Table 4).

Benzene alkylation with ethanol can be considered as an electrophilic substitution on the aromatic ring, and over acidic zeolites. It is commonly considered as proceeding via a carbenium ion-type mechanism [22]. The ethylation of benzene with ethanol has been proposed to take place by the reaction of the activated alkene (formed by dehydration of the alcohol) on the acid sites of the zeolite [23, 24]. 


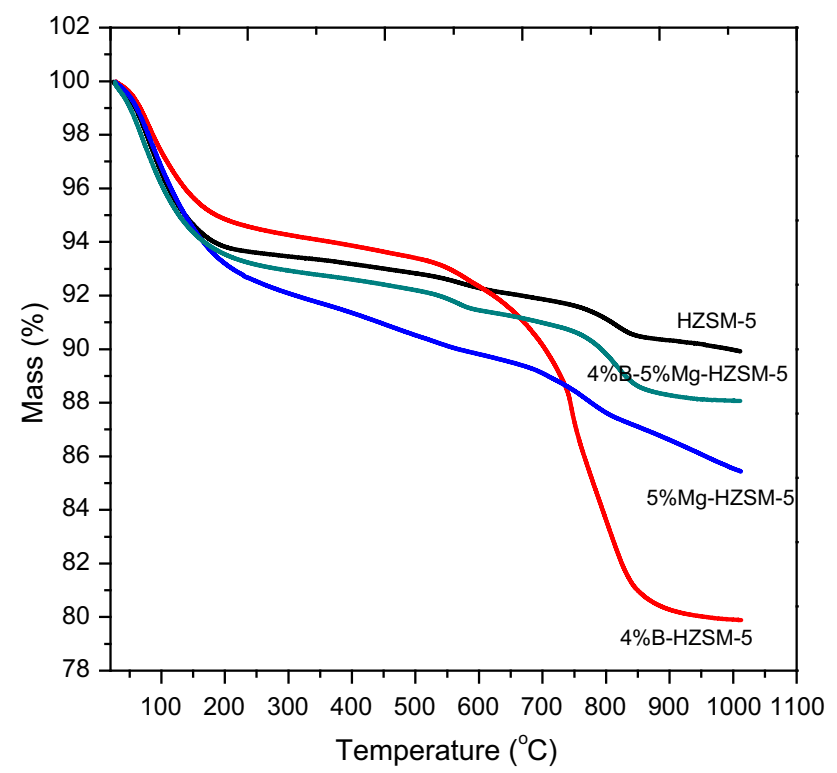

Fig. 7 TGA graph of HZSM-5, $4 \%$ B-HZSM-5, $5 \%$ Mg-HZSM-5 and $(4 \% \mathrm{~B}-5 \% \mathrm{Mg})$-HZSM-5

Table 3 Percent weight loss of modified and unmodified HZSM- 5 by TGA test

\begin{tabular}{lll}
\hline No. & Name of catalyst & TGA percent weight loss $(\%)$ \\
\hline 1 & HZSM-5 & 10.1 \\
2 & B (4 \%)-HZSM-5 & 20.1 \\
3 & Mg (5 \%)-HZSM-5 & 14.5 \\
4 & Mg (5 \%)-B (4 \%)-HZSM-5 & 11.9 \\
\hline
\end{tabular}

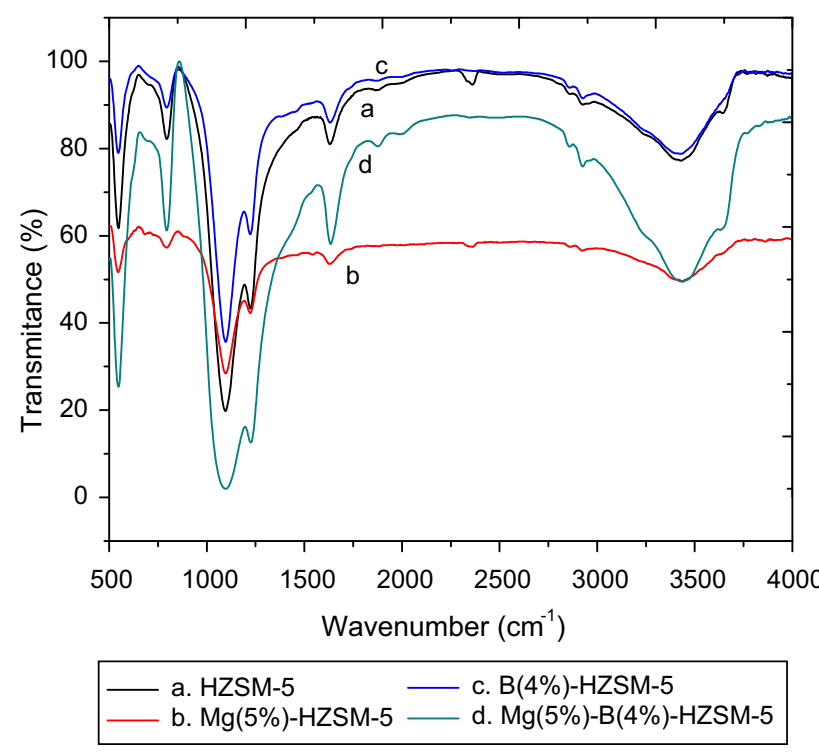

Fig. 8 FTIR spectra of modified and Unmodified HZSM-5 zeolites in the region of framework vibrations

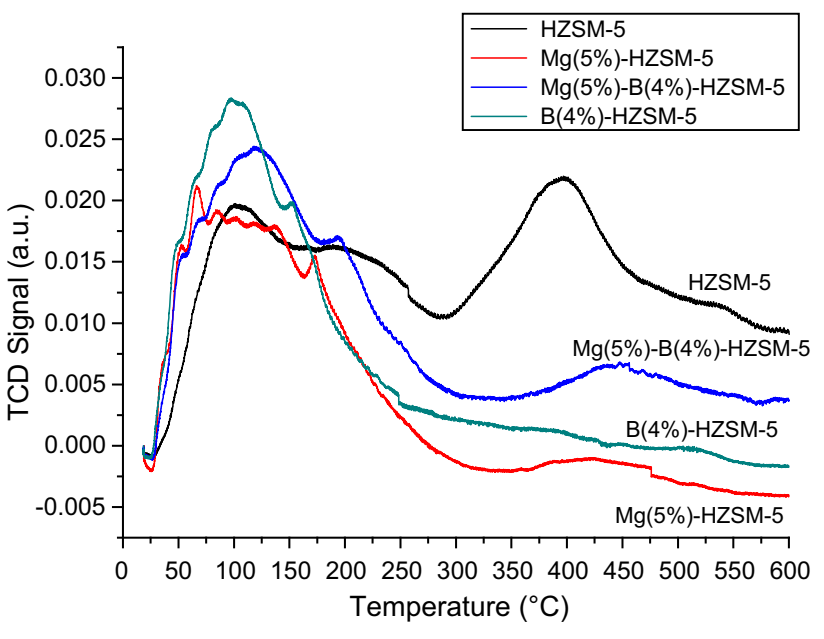

Fig. 9 Ammonia temperature programmed desorption $\left(\mathrm{NH}_{3}-\mathrm{TPD}\right)$ of modified and unmodified HZSM-5

Table 4 Ammonia temperature programmed desorption $\left(\mathrm{NH}_{3}-\mathrm{TPD}\right)$ of modified and unmodified HZSM-5

\begin{tabular}{llll}
\hline No. & Type of catalyst & $\begin{array}{l}\text { Weak acid sites } \\
(\mathrm{mmol} / \mathrm{g})\end{array}$ & $\begin{array}{l}\text { Strong acid sites } \\
(\mathrm{mmol} / \mathrm{g})\end{array}$ \\
\hline 1 & Unloaded HZSM-5 & 5.388 & 2.706 \\
2 & Mg (5 \%)-HZSM-5 & 0.447 & 1.947 \\
3 & B (4 \%)-HZSM-5 & 1.305 & 2.458 \\
4 & Mg (5 \%)-B (4 \%)- & 1.538 & 3.771 \\
& HZSM-5 & & \\
\hline
\end{tabular}

Scientists and researchers have developed different catalysts to make ethanol dehydration more industrial friendly to enhance ethylene yield and lower reaction temperature. Phosphoric acids, oxides, zeolites, and heteropolyacids are catalysts used for acid-catalysed alcohol dehydration. Among the zeolite catalysts, ZSM-5 zeolite is the most widely studied, due to its possibility of catalysing the reaction at lower temperatures, which made it commercially valuable and promising [25].

The disproportionation of toluene to benzene and xylene is known to be catalysed by acidic catalysts such as HZSM-5 and $\mathrm{HY} / \beta-\mathrm{AlF} 3 / \mathrm{Cu}[26,27]$. Various types of zeolites, such as mordenite, USY, Beta, MCM-22 and ZSM-5 catalysts show good catalytic activity and stability in ethylbenzene disproportionation/alkylation using different types of reactor and reaction conditions. The disproportionation of ethylbenzene gives rise to diethylbenzene and benzene [24]

Performance of modified and unmodified HZSM-5 catalysts

In the present study, a comparison between the performances of unmodified and modified HZSM-5 for the alkylation reaction of benzene with ethanol was carried out. Experiments 
were carried out in a fixed catalytic bed down flow reactor at a constant feed (benzene and ethanol mixture $2: 1$ by volume) rate of $0.4 \mathrm{ml} / \mathrm{min}$ and a carrier gas $\left(N_{2}\right)$ flow $0.5 \mathrm{l} / \mathrm{min}(\mathrm{lpm})$. The WHSV of benzene and ethanol mixture as feed was $32.6 \mathrm{~h}^{-1}$ using nitrogen as a carrier gas and to activate catalyst. The products of the reactions were analysed by gas chromatograph. Liquid products contained benzene, ethanol, toluene, ethylbenzene, p-xylene, m-xylene, o-xylene, diethylbenzene and triethylbenzene. The gaseous products contained negligible amount of hydrocarbon gases (ethane, methane, ethylene, etc.).

The following equations were used to check the activity of the catalysts:
$\%$ benzene
$\frac{\text { Moles of benzene converted }}{\text { Moles of benzene in the feed }} \times 100$
2. $\%$ ethylbenzene yield
$\frac{\text { Moles of ethylbenzene obtained }}{\text { Moles of benzene converted }} \times 100$
3. $\%$ ethylbenzene selectivity $\frac{\text { Moles of ethylbenzene (desired product) formed }}{\text { Moles of all products formed }} \times 100$

\section{Unmodified HZSM-5 zeolite catalyst}

Table 5 and Fig. 10 show the effect of reaction temperature on catalytic performance of HZSM-5 catalyst for alkylation of benzene with ethanol. From Table 5, it can be seen that the product contains xylene mixture, ethyl benzene, diethylbenzene, triethylbenzene, unconverted benzene and ethanol. Again it can be seen from Fig. 10 that with the increase in reaction temperature from 300 to $400{ }^{\circ} \mathrm{C}$ the conversion of benzene increased and started to decline beyond that. The benzene conversion passed through a pronounced maximum at $400{ }^{\circ} \mathrm{C}$. But the selectivity of ethylbenzene increased starting from $350{ }^{\circ} \mathrm{C}$ while the highest yield of ethylbenzene was obtained at $450{ }^{\circ} \mathrm{C}$.

\section{Modified HZSM-5 zeolite catalyst}

\section{Magnesium modified HZSM-5 zeolite catalyst}

The results of the alkylation of benzene with ethanol using Mg (5\%)-HZSM-5 as a catalyst are presented in Table 6 and Fig. 11. The products were toluene, xylenes, diethylbenzene, triethylbenzene and ethylbenzene. At reaction temperatures of $400^{\circ} \mathrm{C}, \mathrm{Mg}(5 \%)$-HZSM-5 shows highest conversion of $71.7 \%$.

Ethylbenzene (EB), diethylbenzene (DEB) and triethylbenzene (TEB) were obtained as major products in the alkylation of benzene with ethanol over $\mathrm{Mg}(5 \%)$-HZSM5 catalyst. Small amounts of xylene, toluene and gaseous hydrocarbons were also detected.
Table 5 Effect of reaction temperature on catalytic performance of HZSM-5 catalyst for alkylation of benzene with ethanol

\begin{tabular}{lrrrrr}
\hline Products (mol \%) & \multicolumn{5}{l}{ Temperature $\left({ }^{\circ} \mathrm{C}\right)$} \\
\cline { 2 - 6 } & \multicolumn{1}{c}{$300{ }^{\circ} \mathrm{C}$} & $350{ }^{\circ} \mathrm{C}$ & $400{ }^{\circ} \mathrm{C}$ & $450{ }^{\circ} \mathrm{C}$ & $500{ }^{\circ} \mathrm{C}$ \\
\hline Ethanol & 18.83 & 15.68 & 11.41 & 9.84 & 13.54 \\
Benzene & 41.57 & 33.78 & 30.52 & 32.39 & 41.39 \\
Toluene & 0.71 & 0.56 & 0.68 & 0.84 & 0.47 \\
Ethylbenzene & 22.71 & 23.29 & 28.92 & 33.62 & 30.97 \\
Para-Xylene & 1.55 & 2.82 & 1.48 & 0.78 & 0.29 \\
Meta-Xylene & 0.66 & 1.36 & 1.05 & 0.86 & 0.36 \\
Ortho-Xylene & 0.95 & 1.44 & 1.17 & 0.73 & 0.32 \\
Diethylbenzene & 3.79 & 7.23 & 8.13 & 7.32 & 3.35 \\
Triethylbenzene & 6.68 & 10.01 & 14.97 & 12.81 & 7.21 \\
Others & 2.51 & 3.81 & 1.67 & 0.81 & 2.11 \\
\hline
\end{tabular}

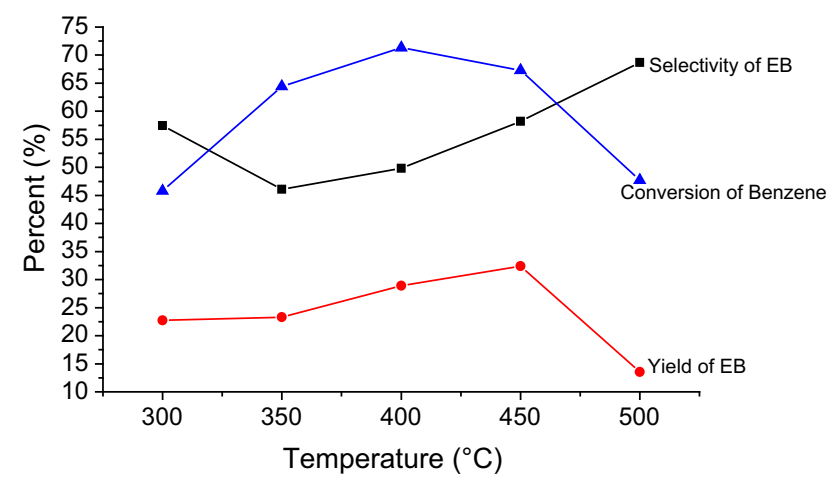

Selectivity of EB (\%) - - Yield of EB (\%) $-\llcorner-$ Benzene conversion (\%)

Fig. 10 Effect of reaction temperature on catalytic performance of HZSM-5 catalyst for alkylation of benzene with ethanol for selectivity and yield of ethylbenzene

Table 6 Effect of reaction temperature on catalytic performance of $5 \% \mathrm{Mg}-\mathrm{HZSM}-5$ catalyst for alkylation of benzene with ethanol

\begin{tabular}{lcrrr}
\hline Products (mol \%) & \multicolumn{5}{l}{ Temperature $\left({ }^{\circ} \mathrm{C}\right)$} \\
\cline { 2 - 5 } & $350{ }^{\circ} \mathrm{C}$ & $400{ }^{\circ} \mathrm{C}$ & $450{ }^{\circ} \mathrm{C}$ & $500{ }^{\circ} \mathrm{C}$ \\
\hline Ethanol & 2.84 & 2.18 & 1.98 & 3.58 \\
Benzene & 35.84 & 27.72 & 32.55 & 40.46 \\
Toluene & 1.4 & 0.84 & 0.66 & 0.66 \\
Ethylbenzene & 29.13 & 31.60 & 33.55 & 33.95 \\
Para-Xylene & 2.24 & 1.86 & 1.24 & 0.58 \\
Meta-Xylene & 1.94 & 1.60 & 1.13 & 0.53 \\
Ortho-Xylene & 1.26 & 1.24 & 0.84 & 0.45 \\
Diethylbenzene & 11.3 & 14.31 & 10.75 & 5.75 \\
Triethylbenzene & 11.88 & 16.44 & 15.27 & 10.46 \\
Others & 2.18 & 2.20 & 2.05 & 3.59 \\
\hline
\end{tabular}




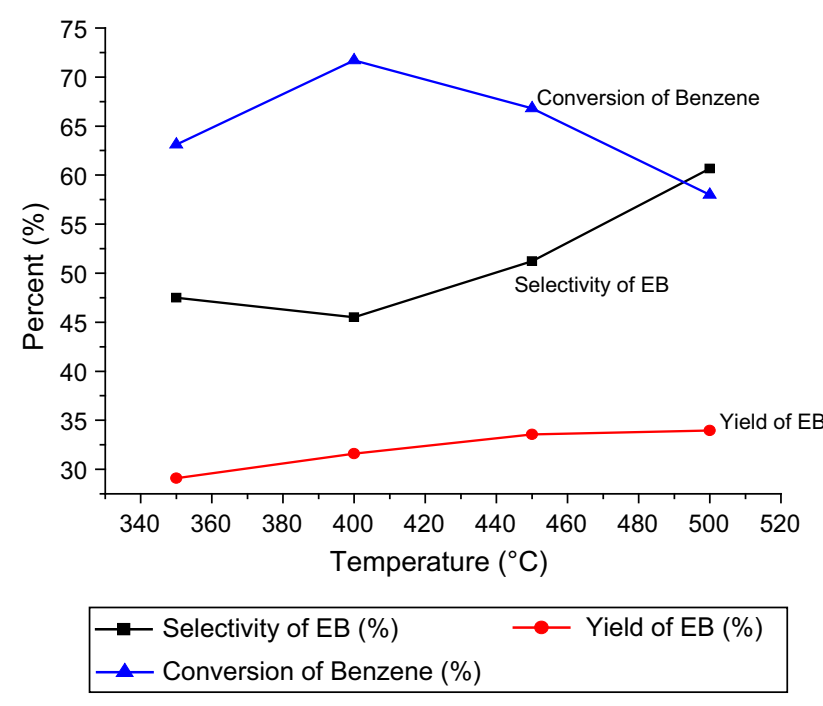

Fig. 11 Effect of reaction temperature on catalytic performance of $5 \% \mathrm{Mg}-\mathrm{HZSM}-5$ catalyst for alkylation of benzene with ethanol for selectivity and yield of ethylbenzene

Figure 11 summarizes the product selectivity during the alkylation of benzene with ethanol over this catalyst. Ethylbenzene was obtained as the most predominant product over this catalyst and might be attributed to its free diffusion without steric hindrance through the pores of the catalysts. Formation of ethylbenzene represents the primary alkylation step, while the alkylation reaction of ethylbenzene with ethanol led to the formation of diethyl benzene, representing the secondary alkylation reaction. Ethylbenzene selectivity over Mg (5\%)-HZSM-5 decreased with increase in benzene conversion and vice versa.

\section{Boron modified HZSM-5 zeolite catalyst}

When ethanol is contacted with benzene in the presence of solid acid catalyst, the alkylating agent can follow (a) alkylation with benzene to produce ethyl benzene, (b) ethylbenzene reacts with ethanol and produce diethylbenzene, and (c) diethylbenzene reacts with excess ethanol to produce triethylbenzene. Table 7 and Fig. 12 show the effect of reaction temperature on catalytic performance of B (4\%)-HZSM-5 catalyst for alkylation of benzene with ethanol. Table 7 shows the formation of xylenes, diethylbenzene, triethylbenzene and ethylbenzene in the products. The highest conversion of benzene was obtained at $400{ }^{\circ} \mathrm{C}$ while the selectivity of ethylbenzene increased with the decrease of benzene conversion.

3. Boron and magnesium bimetallic modified HZSM-5 zeolite catalyst

The effect of reaction temperature on conversion of benzene as well as ethanol (limiting reactant) for the alkylation reaction over $\mathrm{Mg}(5 \%)-\mathrm{B}(4 \%)$-HZSM-5 for benzene to ethanol ratio $(\mathrm{v} / \mathrm{v}) 2: 1$ is shown in Table 8 and
Table 7 Effect of reaction temperature on catalytic performance of $4 \%$ B-HZSM-5 catalyst for alkylation of benzene with ethanol

\begin{tabular}{lllll}
\hline Products (mol \%) & \multicolumn{5}{l}{ Temperature $\left({ }^{\circ} \mathrm{C}\right)$} \\
\cline { 2 - 5 } & $350{ }^{\circ} \mathrm{C}$ & $400{ }^{\circ} \mathrm{C}$ & $450{ }^{\circ} \mathrm{C}$ & $500{ }^{\circ} \mathrm{C}$ \\
\hline Ethanol & 16.48 & 10.09 & - & - \\
Benzene & 55.57 & 34.02 & 38.96 & 46.35 \\
Toluene & - & - & - & - \\
Ethylbenzene & 22.28 & 31.31 & 38.32 & 38.06 \\
Para-Xylene & 5.66 & 2.58 & 1.57 & 0.67 \\
Meta-Xylene & - & - & - & - \\
Ortho-Xylene & - & - & - & - \\
Diethylbenzene & - & 6.42 & 5.35 & 2.94 \\
Triethylbenzene & - & 15.58 & 15.80 & 9.75 \\
Others & - & - & - & 2.23 \\
\hline
\end{tabular}

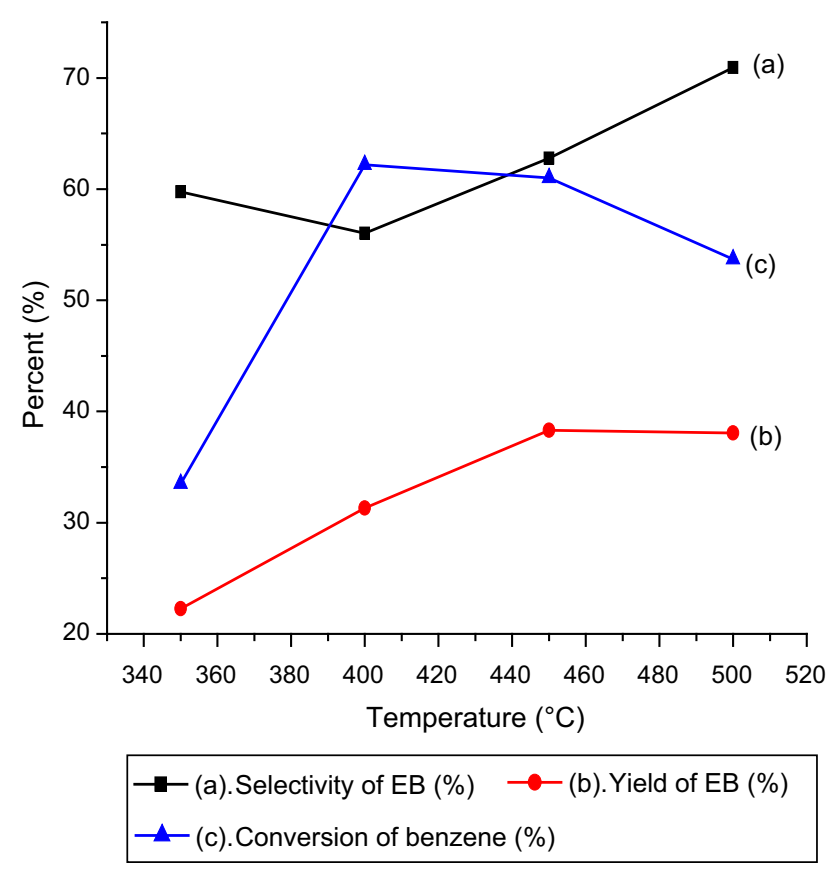

Fig. 12 Effect of reaction temperature on catalytic performance of $4 \%$ B-HZSM-5 catalyst for alkylation of benzene with ethanol for selectivity and yield of ethylbenzene

Fig. 13. In the temperature range of $300-500{ }^{\circ} \mathrm{C}$, the conversion of benzene increased up to $400{ }^{\circ} \mathrm{C}$, and then it started decreasing. The decline in conversion of benzene was probably due to the decomposition of alkylating reagent (ethanol) at higher temperatures. Furthermore, the above reaction temperature of $400{ }^{\circ} \mathrm{C}$, transalkylation reaction and Ethylbenzene disproportionation were played an important role, thereby decreased conversion of benzene. According to Osman et al. (2013), the catalytic experiment in the CREC Riser Simulator showed that low temperature favours the EB ethylation reaction while higher temperature is favourable for disproportionation. 
Table 8 Effect of reaction temperature on catalytic performance of $\operatorname{Mg}(5 \%)-\mathrm{B}(4 \%)-H Z S M-5$ catalyst for alkylation of benzene with ethanol

\begin{tabular}{lrrrll}
\hline Products (mol \%) & \multicolumn{5}{l}{ Temperature $\left({ }^{\circ} \mathrm{C}\right)$} \\
\cline { 2 - 6 } & $300{ }^{\circ} \mathrm{C}$ & $350{ }^{\circ} \mathrm{C}$ & $400{ }^{\circ} \mathrm{C}$ & $450{ }^{\circ} \mathrm{C}$ & $500{ }^{\circ} \mathrm{C}$ \\
\hline Ethanol & 3.00 & 1.82 & 1.89 & 5.09 & 2.93 \\
Benzene & 47.02 & 34.49 & 32.97 & 41.99 & 46.34 \\
Toluene & 0.35 & 0.81 & 0.70 & 0.37 & 0.76 \\
Ethylbenzene & 31.06 & 34.45 & 37.72 & 37.39 & 36.92 \\
Para-Xylene & 6.77 & 4.93 & 2.51 & 0.43 & 0.47 \\
Meta-Xylene & 1.03 & 2.01 & 1.43 & - & - \\
Ortho-Xylene & 0.94 & 1.33 & 0.91 & - & - \\
Diethylbenzene & 2.81 & 8.46 & 9.06 & 3.05 & 2.69 \\
Triethylbenzene & 4.80 & 10.45 & 11.87 & 6.99 & 5.18 \\
Others & 1.81 & 1.24 & 0.94 & 4.69 & 4.70 \\
\hline
\end{tabular}

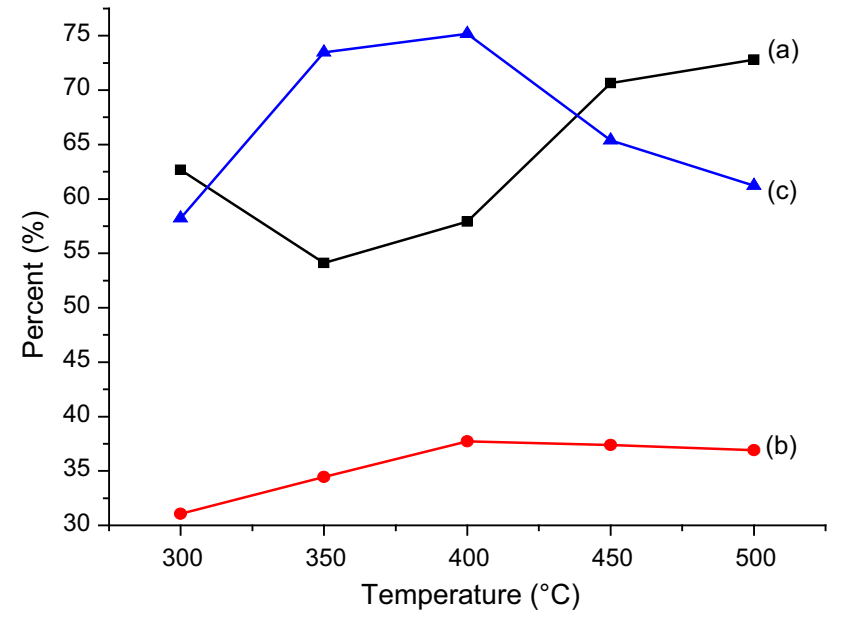

$$
\begin{aligned}
& \rightarrow-(\mathrm{a}) \text {. Selectivity of EB (\%) } \longrightarrow \text { (b). Yield of EB (\%) } \\
& \longrightarrow \text { (c). Conversion of benzene }(\%)
\end{aligned}
$$

Fig. 13 Effect of reaction temperature on catalytic performance of $\mathrm{Mg}(5 \%)-\mathrm{B}$ (4\%)-HZSM-5 catalyst for alkylation of benzene with ethanol for selectivity and yield of ethylbenzene

The effect of reaction temperature on selectivity of ethylbenzene over $\mathrm{Mg}(5 \%)$-B (4\%)-HZSM-5 catalyst for the above-stated ratio of feed is also shown in Fig. 13. Both the selectivity and yield of ethylbenzene were increased with increase in temperature. It appeared that with increase in temperature the diffusion rate was increased and, thereby, the selectivity and para selectivity were also increased. Ethylbenzene was a major product.

\section{Performance comparison of modified and unmodified HZSM-5 catalysts}

As shown in Fig. 14, the highest selectivity of ethylbenzene was obtained with boron modified HZSM-5 for the

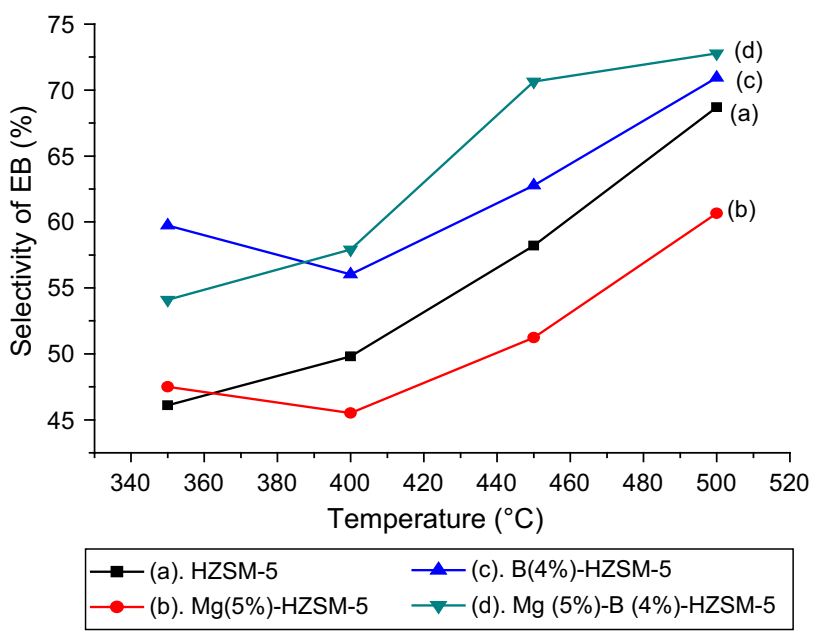

Fig. 14 Selectivity of ethylbenzene (\%) for modified and unmodified HZSM-5

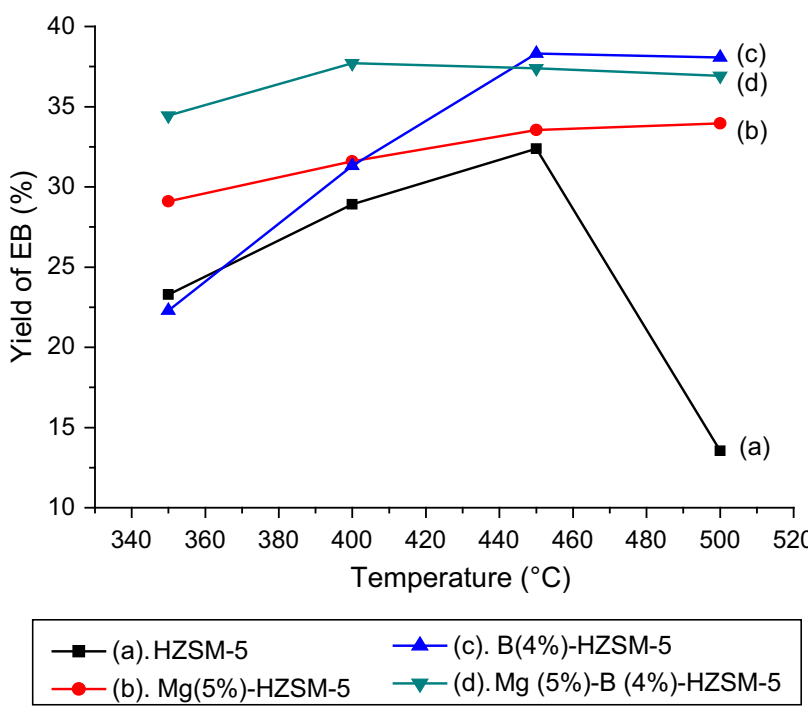

Fig. 15 Yield of ethylbenzene (\%) for modified and unmodified HZSM-5

temperature range below $390{ }^{\circ} \mathrm{C}$. Above this temperature, the highest selectivity of ethyl benzene was obtained using bimetallic (B and Mg) modified HZSM-5. Generally, it was observed that the selectivity of ethyl benzene over $\mathrm{Mg}$ (5 \%)-B (4\%)-HZSM-5 and B (4\%)-HZSM-5 was higher than unmodified HZSM-5. Mg (5\%)-HZSM-5 had lower ethylbenzene selectivity than unmodified HZSM- 5 above $360{ }^{\circ} \mathrm{C}$.

From Fig. 15, the highest yield of ethylbenzene (37.7 \%) was obtained by $\mathrm{Mg}(5 \%)$-B (4\%)-HZSM-5 for the temperature range below $440{ }^{\circ} \mathrm{C}$, while the highest yield $(38.32 \%)$ above $440{ }^{\circ} \mathrm{C}$ was obtained by B $(4 \%)$ HZSM-5. The unmodified HZSM-5 had the lowest yield $(32.39 \%)$ compared to the modified ones. As shown in Figs. 16 and 17, in terms of benzene and ethanol 


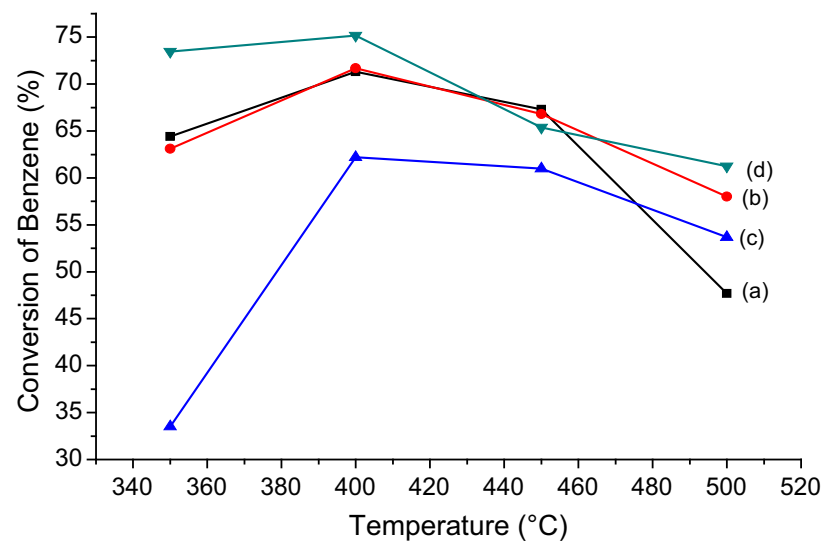

- (a). HZSM-5 - (c). B(4\%)-HZSM-5

(b). Mg(5\%)-HZSM-5 $\longrightarrow$ (d). Mg (5\%)-B (4\%)-HZSM-5

Fig. 16 Conversion of benzene (\%) for modified and unmodified HZSM-5

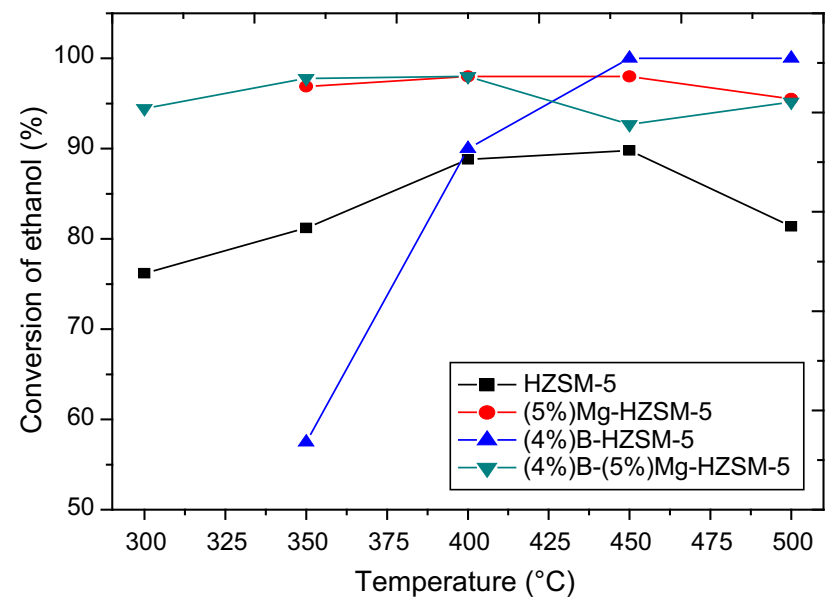

Fig. 17 Conversion of ethanol $(\%)$ for modified and unmodified HZSM-5

conversions $\mathrm{Mg}(5 \%)$-B (4 \%)-HZSM-5 was the best. B (4\%)-HZSM-5 showed lower benzene conversion, while $\operatorname{Mg}(5 \%)$-HZSM-5 showed better benzene conversion relative to unmodified HZSM-5.

\section{Conclusion}

From the experimental results above, we observed the following:

- Ethylbenzene was the primary product while diethylbenzene, triethylbenzene, toluene and xylene mixtures also exist in the product.

- Highest selectivity of ethylbenzene $(72.79 \%)$ and higher conversion of benzene $(75.17 \%)$ were obtained by bimetallic catalyst $[\mathrm{Mg}(5 \%)-\mathrm{B}(4 \%)-\mathrm{HZSM}-5]$ at 500 and $400{ }^{\circ} \mathrm{C}$, respectively.
- Boron modified showed lower benzene conversion $(62.2 \%)$ while magnesium modified showed approximately the same benzene conversion $(71.7 \%)$ when compared to unmodified HZSM-5 (71.3\%).

- The existence of abundant ethanol may facilitate the alkylation of benzene to produce ethylbenzene and then further alkylation to diethylbenzene and tri ethylbenzene. Therefore, it would be essential to do further investigation.

Acknowledgments We thank Hydrocarbon and Instrumentation Analysis Laboratories, Chemical Engineering Department and Institute Instrumentation Centre, IIT Roorkee for their unlimited support.

Open Access This article is distributed under the terms of the Creative Commons Attribution License which permits any use, distribution, and reproduction in any medium, provided the original author(s) and the source are credited.

\section{References}

1. Hossain MM, Atanda L, Al-Yassir N, Al-Khattaf S (2012) Kinetics modelling of ethylbenzene dehydrogenation to styrene over a mesoporous alumina supported iron catalyst. Chem Eng $\mathrm{J}$ 207-208:308-321

2. Agency for Toxic Substances and Disease Registry (ATSDR) (2010) Toxicological profile for ethyl benzene, Atlanta, GA: US, department of health and human services, public health service

3. Chemical Market Associates (2004) World Light Olefins Analysis, vol I and II, Houston, Texas, http://www.ethylbenzene.org/ content/bibliography.html

4. Degnan TF Jr, Smith CM, Venkat R (2001) Alkylation of aromatics with ethylene and propylene: recent developments in commercial processes. Appl Catal A Gen 221:283-294

5. Netzer D (1999) Integrate ethylbenzene production with an olefins plant. Hydrocarbon Process 78:77-88

6. Perego C, Ingallina P (2002) Recent advances in the industrial alkylation of aromatics: new catalysts and new processes. Catal Today 73:3-22

7. Smirnov V, Mazin V, Yuschenko V, Knyazeva E, Nesterenko N, Ivanova I, Galperin L, Jensen R, Bradley S (2000) Benzene alkylation with propane over Pt-modified MFI zeolites. J Catal 194:266-277

8. Hoelderich WF (2000) Environmentally benign manufacturing of fine and intermediate chemicals. Catal Today 62:115-130

9. Mitsutani A (2002) Future possibilities of recently commercialized acid/base-catalysed chemical processes. Catal Today 73:57-63

10. Chandawar H, Kulkarni B, Ratnasamy P (1982) Alkylation of benzene with ethanol over ZSM-5 zeolites. Appl Catal 4:287-295

11. Odedairo T, Al-Khattaf S (2010) Kinetic investigation of benzene ethylation with ethanol over USY zeolite in riser simulator. Ind Eng Chem Res 49:1642-1651

12. Bellussi G, Pazzuconi G, Perego C, Girotti G, Terzoni G (1995) Liquid-phase alkylation of benzene with light olefins catalysed by $\beta$-zeolites. J Catal 157:227-234

13. Venuto PB, Hamilton LA, Landis PS (1966) Organic reactions catalysed by crystalline aluminosilicate II. Mechanistic and aging considerations. J Catal 5:484-493 
14. Becker KA, Karge HG, Streubel WD (1973) Benzene alkylation with ethylene and propylene over H-mordenite as catalyst. J Catal 28:403413

15. Corma A, Liopis FJ, Martínez C, Sastre G, Valencia S (2009) The benefit of multipore zeolites: catalytic behaviour of zeolites with intersecting channels of different sizes for alkylation reactions. J Catal 268:9-17

16. Odedairo T, Al-Khattaf S (2010) Ethylation of benzene: effect of zeolite acidity and structure. Appl Catal A Gen 385:31-45

17. Li J, Wang Y, He J, Zhu Z (2012) Alkylation of benzene with ethanol on zeolites modified with $\mathrm{La}_{2} \mathrm{O}_{3}$. Adv Mater Res 347-353:3670-3676

18. Zhang C et al (2013) Effects of alkaline-earth metals on the structure, adsorption and catalytic behaviour of iron-based FischerTropsch synthesis catalysts. Appl Catal A Gen 464-465:10-19

19. Rodriguez-Gonzalez L, Hermes F, Bertmer M, RodriguezCastellon E, Jimenez-Lopez A, Simon U (2007) The acid properties of H-ZSM-5 as studied by $\mathrm{NH}_{3}$-TPD and Al-MAS-NMR spectroscopy. Appl Catal A Gen 328:174-182

20. Post JG, van Hooff JHC (1984) Acidity and activity of H-ZSM-5 measured with $\mathrm{NH}_{3}$-TPD and n-hexane cracking. Zeolites 4:9-14

21. Lü R, Tangbo H, Wang Q, Xiang S (2003) Properties and characterization of modified HZSM-5 zeolites. J Nat Gas Chem $12: 56-62$
22. Siffert S, Gaillard L, Su L (2000) Alkylation of benzene by propylene on a series of beta zeolites. J Molec Catal A Chem 153:267-279

23. Corma A, Martinez-Soria V, Schnoeveld E (2000) Alkylation of benzene with short chain olefins over MCM-22 zeolite, Catalytic behaviour and kinetic mechanism. J Catal 192:163-173

24. Osman M, Atanda L, Hossain M, Al-Khattaf S (2013) Kinetics modelling of disproportionation and ethylation of ethylbenzene over HZSM-5: effects of $\mathrm{SiO}_{2} / \mathrm{Al}_{2} \mathrm{O}_{3}$ ratio. Chem Eng $\mathrm{J}$ 222:498-511

25. Xin Hongchuan, Li Xiangping, Fang Yuan, Yi Xianfeng, Hua Wenhui, Chu Yueying, Zhang Feng, Zheng Anmin, Zhang Hongpeng, Li Xuebing (2014) Catalytic dehydration of ethanol over post-treated ZSM-5 zeolites. J Catal 312:204-215

26. Meshram NR, Hegde SG, Kulkarni SB, Ratnasamy P (1983) Disproportionation of toluene over HZSM-5 zeolites. Appl Catal 3:359-367

27. Aneke LE, Gerritsen LA, Van Den Berg PJ, De Jong WA (1979) The disproportionation of toluene over a $\mathrm{HY} / \beta-\mathrm{AlF} 3 / \mathrm{Cu}$ catalyst. J Catal 59:26-36 